\title{
Routine But Ribald. Intimacy in Stefan Żeromski’s Journals
}

Stefan Żeromski's Dzienniki [Journals] are undeniably one of the most famous texts of the $19^{\text {th }}$-century Polish intimate diary writings. The author of Ludzie bezdomni [Homeless People] wrote his diary between 1882 and 1891. His lively correspondence with his fiancée (and future wife), Oktawia Rodkiewiczowa, started to fulfil the memoiristic function at that time ${ }^{1}$.

According to Stanisław Piołun-Noyszewski, Żeromski's relative and biographer during the interwar period, private records of the writer were supposedly quite innocent in character. "They include literary attempts, idealistic erotic poems and glued-in letters from his first love"2, Noyszewski wrote in 1928. Two post-war editions of Dzienniki verified this. Roman Zimand noted that "scholars, and probably common readers as well, believe that where eroticism was concerned, Dzienniki did not shy away from drastic descriptions. It was quite remarkable in the $19^{\text {th }}$ century that Żeromski, the diary-writer, was far bolder when writing about eroticism than Żeromski, the novelist"3.

In reference to the uncensored handwritten material, ${ }^{4}$ such a thematic classification is even more justified. Therefore, Żeromski's Dzienniki can be viewed both as a literary training ground and as a record of a young man maturing and entering the realm of $\operatorname{sex}^{5}$. Hence the strong presence of the subject of morality next to multiple literary attempts and reviews of books and theatre plays. If we narrow it down to the eroticism-related issues, we will find the following list of subjects: autoeroticism, sexual initiation, sexual experiences associated with both

* Dr, e-mail: kkosciewiczgmail.com; Uniwersytet w Białymstoku, Instytut Filologii Polskiej, 15-420 Białystok, Plac Uniwersytecki 1.

${ }^{1}$ Discussed by Z.J. Adamczyk and Z. Goliński in Nota wstępna to: S. Żeromski, Dziennik $z$ wiosny 1891, Kielce 2000, pp. 7-8.

2 S. Piołun-Noyszewski, Stefan Żeromski. Dom, dzieciństwo i młodość, Cracow 1928, p. 4.

${ }^{3}$ R. Zimand, Diarysta Stefan Ż. [Stefan Ż., the diarist], Wrocław 1990, p. 76.

${ }^{4}$ To be found in repositories of the National Library. Available in the form of microfilms.

${ }^{5}$ Cf. P. Rodak, Miłość $w$ dzienniku Stefana Żeromskiego: między sztambuchem, listem i powieścia, "Pamiętnik Literacki" 2010, no 2; idem, Między zapisem i literaturą. Dziennik polskiego pisarza w wieku XX, Warsaw 2011. 
paid love and love free of the mercantile liability, and venereal disease, which Żeromski suffered from several times. Our insight into his personal affairs is not limited to the author and his partners. It is worth noting that, occasionally, Żeromski allowed us to see his closest surroundings.

As far as the Dzienniki are concerned, the problem of self-censorship and morality-related censorship is an interesting issue. An analysis of the private records of the author of Dzieje grzechu [A Story of Sin], conducted for that very purpose, will allow us to answer two questions. First, how didŻeromski write about private issues? Second, which issues, and to what extent, were these issues considered taboo for Żeromski himself, society in general, readers of the hand-written diary, and finally, the editors of two $20^{\text {th }}$-century book editions ${ }^{6}$.

One of the most important features of Żeromski's Dzienniki were their honesty and openness in accounts related to eroticism. The author's noted represent another step in the evolution of personal document literature. Starting with the Saxon period, more and more attention was devoted to personal issues, breaking the convention of writing about events "fin order to introduce new, emotional motifs in order to "talk about oneself'," as Hanna Dziechcińska noted,"7 Żeromski was surely pushed towards honesty both by the example of his predecessors and his youth. His version of it is nonconformist, extremely emotional, inspired by such literary masters as Aleksander Świętochowski, known for his acute critical writings (as the editor of initially Przeglad Tygodniowy and later Prawda) or French naturalists Guy de Maupassant and Emil Zola ${ }^{8}$.

To some extent that honesty, which often became an intentional violation of taboo, could be evaluated through the analysis of literary ideas of Żeromski recorded in his Dzienniki. Pierwszy raz [The First Time], a draft describing the

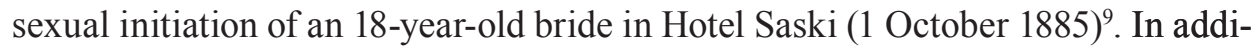
tion, a 26 January 1887 entry read: "Yesterday when I was writing $Z$ teki obiektywisty [From the Objectivist's File], I saw a meeting of a brother and a sister in ojkema, or a regular brothel in other words. " 10 An interesting thing to mention

${ }^{6}$ S. Żeromski, Dzienniki, study by W. Borowy, S. Adamczewski, J. Kądziela, preface by A. Wasilewski, $1^{\text {st }}$ ed., Warsaw 1953-1956, vol. 1-3. S. Żeromski, Dzienniki, preface and study by Jerzy Kądziela, $2^{\text {nd }}$ ed., Warsaw 1963-1970, vol. 1-7. S. Żeromski, Dzienników tom odnaleziony, preparation for printing, preface and notation by J. Kądziela, Warsaw 1973.

${ }^{7}$ H. Dziechcińska, Pamiętniki czasów saskich. Od sentymentalizmu do sensualizmu, Bydgoszcz 1999, p. 62.

8 "Naturalism! Zola, Maupassant, Alexis, Goncourtowie, Dostojewski - they will all squint their eyes before wondrous details of my muse," noted Żeromski in one of his entries. S. Żeromski, Dzienniki, $2^{\text {nd }}$ ed., vol. 5, p. 165.

${ }^{9}$ Roman Zimand hypothesized that the draft was written by Żeromski in order to convince his lover to intensify their relations. Cf. R. Zimand, op. cit., pp. 82-85.

${ }^{10}$ S. Żeromski, Dzienniki, $2^{\text {nd }}$ ed., vol. 3, p. 123. 
is a review of a drawing by Adam Wiślicki, editor of "Przegląd Tygodniowy", to whom Żeromski sent a text with hopes for publishing:

Dear Sir! The drawing not only is not objective but also untrue in the tiniest detail. Why do young people, beginner writers, take worthless delight in the filth?... A pity! There are imaging capabilities ${ }^{11}$.

On 13 June 1888 Żeromski noted down an idea for another, also moralityrelated, short story:

He saw her for the last time in his life when the mountains of misery tumbled onto his shoulders, when he lost all will to work, to live. She refused a kiss out of trivial stubbornness. She made up her mind - and decided to be chaste. But she deceived him eagerly, she toyed with him with delight. It was then that he learned that she let him down forever. It was that blow that was the final straw in his life. Then on a lonely night, when he was listening to the rustle of cherry leaves through an opened window - the idea for revenge came to his mind. (...) He did an easy thing: he wrote to his beloved's husband, told him everything, marked every detail. (...) The husband (...) asked him for a meeting. They met. Then the lover, the challenged, raised his revolver first... and killed the husband of his beloved. He then went to the police and reported the accident. The rest is boring ${ }^{12}$.

The scale of honesty of the diary records could also be seen in the reactions of people who read it. One such interesting account came from Janek, Żeromski's secondary school friend, who "was disappointed reading the filthy paper sheets!"13. The source for that criticism could be found based on the content of the analysed volumes $(1-5)^{14}$, autoerotic practices and sexual contacts of Żeromski and his friends with prostitutes. The reaction of Oktawia Rodkiewiczowa, whom Żeromski asked to read all his records during their engagement period, was even more revealing. The decision to postpone the wedding showed how difficult it was for even a 30-year-old, experienced woman (a widow and mother to a small girl) to read his account considering the morality-related elements included in $\mathrm{it}^{15}$.

\footnotetext{
${ }^{11}$ Ibidem, p. 159.

${ }^{12}$ S. Żeromski, Dzienniki, $2^{\text {nd }}$ ed., vol. 5, p. 140-141.

${ }^{13} \mathrm{~S}$. Żeromski, Dzienniki, $2^{\text {nd }}$ ed., vol. 2, p. 21.

${ }^{14}$ In the article, I used the term "volume" in reference to hand-written journals by Żeromski and the term "collection" in reference to the division used in printed editions.

${ }^{15}$ The account is known from Henryka Witkiewiczowa, nee Rodkiewicz diaries. Cited after: Kalendarz życia i twórczości, S. Eile and S. Kasztelowicz (eds.), Cracow 1976, p. 116.
} 
The indicated honesty of his records, sometimes exhibitionist in form, was not, however, equivalent to a rejection of all inhibitions ${ }^{16}$. Self-censorship appeared in Dzienniki for three reasons: shame, respect for cultural taboo and selfcreation. In all instances, it is related to the issue of morality. Depending on how much shame was internalised by Żeromski, he used different instruments of the Aesopian language. He omitted some subjects with almost utter silence, e.g. his relationships with his sisters. Others he coded, like autoeroticism and paid love. Most frequently, however, he used metaphor, allusion, circumlocution, and ellipsis. He used them mainly when recording his sexual experiences. It is evident that the strongest instrument of the Aesopian language, arising from rejection, is silence. According to the dictionary differentiation of these concepts ${ }^{17}$, he use of a language code is associated with the feeling of shame, i.e. a situation when we decide that something is inappropriate, and it is a considerably internalised process. The use of metaphor, allusion, circumlocution and ellipsis isassociated, on the other hand, with cultural taboo, an external compulsion not to write about certain matters arising from good upbringing and social status, fear of being vulgar, and with Zeromski's desire to createa specific image in the eyes of his readers (or reader-mistresses). Zeromski's choice of Aesopian language instruments corresponded to his age: the older he got, the less restrained he was in his writings.

Artur Hutnikiewicz noted that "Żeromski was raised in an undoubtedly religious home. During his early years spent at school, he was, as confirmed by his own records, a pious and devoted boy, and then adolescent"18. The first symptoms of the crisis of faith came in the later grades of secondary school. The period, during which Żeromski entered puberty, offered records depicting the dramatic struggle of an 18-year-old trying to preserve his moral chastity. The pressure of religious morality was so strong that all the records relating to autoeroticism were meticulously coded in volumes 1,2 and $3^{19}$. It is also shown by a note made in volume five, where the 21-year-old Żeromski described, with disgust and disbelief, his friend:

Stanisław (...) started to talk about his current physiological-moral mood. He consciously committed the last act of this crime three weeks ago! Now, he said, the mood returns leading him to the crime each day. What an awful character, what a disgusting

${ }^{16}$ Cf. J. Paszek, Danae Żeromskiego, "Teksty" 1974, no 1, p. 71. Jerzy Paszek stated that "in Dzienniki the images of love are realistic, with no poetic colouring and no internal censorship". This was contested by Roman Zimand. See: R. Zimand, op. cit., p. 74.

${ }^{17}$ Elaborated upon by Kamila Budrowska in Cenzura, tabu $i$ wstyd. Cenzura obyczajowa w PRL-u (1948-1958), "Napis" 2012, S. XVIII: Tabu i wstyd w literaturze i kulturze, pp. 229-232.

${ }_{18}$ A. Hutnikiewicz, Żeromski, Warsaw 2000, p. 36.

${ }^{19}$ S. Żeromski, Dzienniki, ${ }^{\text {nd }}$ ed., vol. 1, pp. 127, 138, 221, 264. 
creature was there before my eyes! This man, the greatest thinker among us, the most talented pupil in the secondary school, is an onanist! He passionately drinks vodka in order to silence his conscience, memory, and mind. Out of some unstoppable mercy, I have entered the stinking pit of his suffering $(\ldots)^{20}$.

The fact that his friend was a homosexual surely supported the perception of autoeroticism through radically religious (as a "vice" or a "crime") and medical (as "disease") categories. What is interesting is that Żeromski simply reported on the fact. He did not dwell on that fragment of Stanislaw's confession. He instead summarized it all with a general reflection that his friend's life was "a rotten puddle of mud. "21 Żeromski's diary records showed that in the secondary school period he sought the ideal of manly purity, advocated in guides by Samuel Smiles Self-Help and Character ${ }^{22}$. The author postulated the need to master one's instincts since only through moral purity, virtuous life, and work can manly character take shape. The $19^{\text {th }}$-century struggle with "instinct", "desire", "unbridled temperament", "immature energy" and "passion" was realised, according to Ewa Paczoska, through "quite solid recommendations concerning, e.g. sexual education of young men, frightened with the image of masturbation as the main source of diseases of the body and the soul" 23 .

Secondary school students perceived onanism as a greater sin against moral purity than buying the services of prostitutes. Therefore, they shamefully hid it from their peers; it was a taboo, and it was treated pharmaceutically ${ }^{24}$. Sexual relations with mistresses and prostitutes received far less criticism from Żeromski. He did code the information about sexual initiation, which took place during a visit to a prostitute ${ }^{25}$, but he was much more open about it a year later in his diary $^{26}$. Żeromski disguised the temptation to use the services of a prostitute in a metaphor of a blood devil and described his internal struggles a number of times. Not always did his morality prevail over passion, as demonstrated by the several instances of venereal disease he suffered from when composing the diary. He was no different from his peers. Iza Moszczeńska, discussing a survey conducted in 1903 among 140 male students of the Technical University of Warsaw

${ }^{20}$ S. Żeromski, Dzienniki, $2^{\text {nd }}$ ed., vol. 2, p. 93.

${ }^{21}$ Ibidem, p. 95.

${ }^{22}$ Traces of those texts can be found, for example, in the first collection of Dzienniki. S. Żeromski, Dzienniki, 2 ${ }^{\text {nd }}$ ed., vol. 1, pp. 209-212, 214, 218, 222, 223, 226.

${ }^{23}$ E. Paczoska, Ideał czystości i piekło mężczyzn w literaturze drugiej połowy XIX wieku, in: Kobieta i rewolucja obyczajowa. Społeczno-kulturowe aspekty seksualności. Wiek XIX i XX, A. Żarnowska and A. Szwarc (eds.), Warsaw 2006, p. 62.

${ }^{24}$ It can be deduced on the basis of an entry dated 17 January 1883 r., S. Żeromski, Dzienniki, $2^{\text {nd }}$ ed., vol. 1, p. 139.

${ }^{25}$ Ibidem, p. 271.

${ }^{26}$ S. Żeromski, Dzienniki, $2^{\text {nd }}$ ed., vol. 2, pp. 50-51. 
showed that they underwent their sexual initiation between the ages of 16 and 19 , and about $40 \%$ of them suffered from venereal diseases, some repeatedly ${ }^{27}$. Using the services of prostitutes was a rather standard practice amongst Żeromski's colleagues. The resulting diseases affected both men and women of his social class. A telling example was the history of an affair of the author of Dziennik with his stepmother's sister. It was almost a recreation of the events of the autobiographical novel by Gabriela Zapolska - O czym się nawet myśleć nie chce [What You Don't Even Want to Think About]. The novel described a family suffering from a venereal disease. The situation was even more tragic when readers learn that the husband infected not only his wife but also their unborn child. It was the child that paid the ultimate price for the father's sexual freedom - the child died due to venereal complications ${ }^{28}$. In Żeromski's biography, the story is the other way around - the wife became infected through sex with a lover, who used the services of prostitutes. She then infected her husband in their bedroom. Both lovers went out of their minds suspecting, falsely, that she was pregnant. The situation is both tragic and comical since the husband, also unfaithful, blamed himself for his wife's condition. At the same time, the lover was happy about the married couple's sexual abstinence.

The husband was so preoccupied with his gonorrhoea and stomach pain that he has completely forgotten his horns... Yesterday, when he was about to leave for work, he wished Helena "good luck..." We are setting nicely, but the gonorrhoea does its job, too. Every cloud has a silver lining... It was worth it; now the gonorrhoea separates that couple quite fine ${ }^{29}$.

Żeromski's partner, unlike Marysia in Zapolska's novel, was an experienced woman and quietly sought help from a Warsaw doctor ${ }^{30}$. It can be cautiously concluded that venereal diseases were common in Żeromski's society and, as a result, they were a standard conversation subject, also in the presence of young, unmarried ladies. A testament to that fact was the 7 June 1886 entry, inspired by a conversation with his friend, Ms. Celina Żółkowska:

${ }^{27}$ I. Moszczeńska, Czego nie wiemy o naszych synach - fakta i cyfry dla użytku rodziców, Warsaw 1904, pp. 42-48.

${ }^{28}$ Aleksandra Grotowska on Zapolska and reception of her novel: "O czym się nawet myśleć nie chce" a jednak trzeba mówić. O dziełach Gabrieli Zapolskiej i ich recepcji w środowisku współczesnym autorce, "Napis" 2009, S. XV: Umysty zniewolone. Literatura pod presja, pp. 253-266.

${ }^{29} 15 / 08 / 1886$ entry, vol. 9. Manuscript held in the National Library of Poland, Warsaw ref. no. mf. 1330.

${ }^{30}$ 09/07/1886 entry, vol. 9. Manuscript held in the National Library of Poland, Warsaw ref. no. mf. 1330. 
... leaving our place, she advised me not to see her out (her mother was there) "since such late hour carries the risk of a disease..." Great Jehovah, even spinsters know about my illness! Forget the parson, but spinsters... Run, Stefek, from Kielce because excommunication is at hand... The parson backbites me ignominiously, to tell the truth... however, I forgave him for he does not know what he does... It was all dr Strawiński's doing. He revealed the damned "orchitis". It is said a bad memory comes from a bad thing. In the end, it does not have to be that bad... if it does not hurt $m \mathrm{e}^{31}$.

The quoted fragment shows that self-censorship was also known from the Saxon diaries. When describing intimate situations, their authors frequently employed Latin phraseology which limited, due to the language barrier, obscene meaning of the erotic content ${ }^{32}$. There were examples of self-censorship in the $17^{\text {th }}$-century medical guide by Stanisław Sławkowic who used Latin to inform about intimate matter ${ }^{33}$. It seems that Żeromski was familiar with that motivation and used Greek and Latin phrases when his private life met medicine. Żeromski's reserve in writing about private issues also resulted from the fear of being too literal, too vulgar. Żeromski the diarist was more concerned with emotions than physiology. It was often the case that he refrained from putting down a word, or emotion, which could violate his artistic taste through literalness or association with an anatomical detail ${ }^{34}$. That happened, for example when he wrote about moral objections of a mistress, which were reflected in certain limits she set in her bedroom. "I cannot explain it literally because it is drastic for me. All, all of my dreams came through. And yet... she allows for much and not enough at the same time" 35 . Several paragraphs later he voiced the feeling of dissatisfaction and constraint which, indirectly, made the internal self-censor visible: "Oh, let all of these sheets be covered in this red lava river, slowly flowing through my veins... As a black angel, I go to sleep..."36 The author's attention was focused, to a large extent, on the artistic shape of his memoirs. A testimony to that was the entry of 14 October 1885 , his $21^{\text {st }}$ birthday:

${ }^{31}$ 07/05/1886 entry, vol. 9. Manuscript held in the National Library of Poland, Warsaw ref. no. mf. 1330.

${ }^{32}$ I. Maciejewska, "Te rzeczy...” - przejawy autocenzury w prezentowaniu treści erotycznych (na przykładzie prozy czasów saskic), "Napis" 2009, S. XV: Umysly zniewolone, literatura pod presja, pp. $70-71$.

${ }^{33}$ M. Krzysztofik, "O niepłodności w stanach matżeńskich” - czyli jak XVII-wieczny kalendarzysta-lekarz omawia oraz cenzuruje tematy wstydliwe, "Napis" 2009, s. XV: Umysty zniewolone, literatura pod presja, p. 44.

${ }^{34}$ See, e.g. 28/08/1889 entry, S. Żeromski, Dzienniki, $2^{\text {nd }}$ ed., vol. 6, p. 206.

${ }^{35}$ S. Żeromski, Dzienniki, $2^{\text {nd }}$ ed., vol. 2, p. 313.

${ }^{36}$ Ibidem, p. 314. 
She came back from town and laid her hand on my forehead... and gone was all the sadness and feeling of sorrow... Later, the evening hour... The lovely hour! The last pages will I devote to such hours. Not now. Later, when watched through a prism of idealism, it will be beautiful ${ }^{37}$.

It seems that Żeromski's tendency to idealize his partner and their mutual feelings frequently protected the diarist from obscenity and, therefore, from crossing cultural taboo in the way he talked about intimate relations. It should be stressed, however, that apart from elevated, lyric style, Dzienniki also features a low style. Roman Zimand noted that the diarist "could write about eroticism not only in the lyrical style". He could make the account humorous or brutal, almost naturalistic, including drastic details. The researcher was correct, in my opinion, to try and convince us that when compared to the lyrical parts, the naturalistic ones were in the minority and referred to casual, or problematic, mistresses ${ }^{38}$.

Information encoding and euphemisation of his declarations in Żeromski's notes was related to the fact that the journal was made public. Apart from his secondary school friend and his fiancée, we know of a number of other people who read his diaries. Those included: Antoni Gustaw Bem, his secondary school Polish language teacher; Ludwika Borkowska, his sweetheart; and Helena Radziszewska, his mistress. According to Roman Zimand, the autumn 1885 entries concerning Radziszewska were a kind of a cipher, a coded means of communication with both lovers, or a form of putting pressure on the woman who still was not his $^{39}$. Żeromski's lovers and female readers of his private writings were his first censors. A description of the state of the manuscript left in the first printed version of Dzienniki leaves no doubt that the morality-related interventions were quite frequent. That is indicated by crossed out words, and torn out or cut out pages ${ }^{40}$.

The lack of coherence of the printed text due to moral issues resulted from, among other things, decisions made by editors and typesetters. Let us be reminded that Dzienniki in its full version (except political and morality-related cuts) was published twice by the "Czytelnik" publishing house. In both cases, it was in the period of the People's Republic of Poland (PRL). The first edition was published in years 1953-1956. It was edited by Wacław Borowy, Stanisław Adamczewski, and Jerzy Kądziela. The next edition entered production ten years later. The second edition was published as part of Dzieła [Works] - a huge project to publish Żeromski's works, edited by Stanisław Pigoń. He was, in fact, responsible for the content supervision of the second edition of Dzienniki. Jerzy Kądziela, involved in the first edition, was responsible for typesetting. The new edition was updated

\footnotetext{
${ }^{37}$ Ibidem, p. 313.

${ }^{38}$ R. Zimand, op. cit., pp. 94-96.

${ }^{39}$ Ibidem, pp. 82-85.

${ }^{40}$ See, among others, S. Żeromski, Dzienniki, $2^{\text {nd }}$ ed., vol. 2, pp. 75, 302, 313, 351.
} 
with two previously unpublished volumes, corrected and extended considerably, in comparison with the 1950 s edition. It took publishers seven years to finish the project (1963-1970); and if we include also Dzienników tom odnaleziony, the period covered ten years (1963-1973).

The morality-related content in Dzienniki was the greatest editorial problem of both editions ${ }^{41}$. At the beginning of the 1950s, Żeromski's wife and daughter disagreed with publishing the diary. They referred to Żeromski's verbal provision that his works were not to be published for 50 years following his death. The condition was disregarded in the case of both publications ${ }^{42}$. A compromise was to introduce moral censorship. The author of the Preface to the first edition defended the editors from the accusation of seeking scandal by writing, among other things: "out of respect for the author's will, the published text omits certain intimate and drastic issues, a condition put in his testament" ${ }^{\text {"43 }}$. The Editorial note repeated the note from the Preface regarding the omission of those fragments of the writer's manuscript "which applied to more personal matters" ${ }^{4}$. The second edition also included morality-related cuts. However, in the Preface to collection 1 of the 1963 edition, Jerzy Kądziela explained that the $1^{\text {st }}$ and $2^{\text {nd }}$ editions were mostly different in terms of the number of omissions

which far fewer than in the $1^{\text {st }}$ edition of Dzienniki. The editors returned intimate sections of the text in the belief that the author himself was conscious of the possibility that his works would be read by incidental readers and future generations $(\ldots)^{45}$.

When removing the "intimate and drastic" fragments the editors of the first edition considered as unprintable: morality-related issues concerning Żeromski's closest family - his stepmother and sisters, autoeroticism, venereal disease, details of his sex life (visits to prostitutes, descriptions of intercourse), and the author's comments on other people (e.g., implying incest). The greatest number of omissions could be found in the volumes edited by Stanisław Adamczewski (volumes 3-15). Compared to those, the text edited by Wackaw Borowy (volumes 1-2) and Jerzy Kądziela (volumes 17-21) retained greater coherence. To some extent it was the content itself that had some influence on the extent of censorship. Volumes edited by Adamczewski described the tumultous period of Żeromski's affair with

${ }^{41}$ The political tone of the diary was as important. Beata Utkowska touched upon the subject in Sporny wzorzec rusofobii. Stefan Żeromski wobec Rosji i Rosjan w "Dziennikach" (typescript). I approach this issue in Intymistyka i cenzura - na przykładzie pierwszego wydania "Dzienników" Stefana Żeromskiego, in: "Lancetem a nie maczuga". Cenzura wobec literatury i twórców w latach 1945-1965, K. Budrowska and M. Woźniak-Łabieniec (eds.), Warsaw 2012, pp. 179-193.

${ }^{42}$ More on the subject, in: K. Kościewicz, op. cit.

${ }^{43}$ A. Wasilewski, Przedmowa in: S. Żeromski, Dzienniki, $1^{\text {st }}$ ed., vol. 1, p. 5.

${ }^{44}$ Editorial note, in: S. Żeromski, Dzienniki, ${ }^{\text {st }}$ ed., vol. 1, p. 40.

45 J. Kądziela, Przedmowa, in: S. Żeromski, Dzienniki, $2^{\text {nd }}$ ed., vol. 1, p. 40. 
Helena Radziszewska and venereal disease problems, which he suffered from several times in his youth. It was not the only factor, however. An analysis of the entire material suggests that personal views of editors might have also influenced it. One suspects that they respected different editing rules and they differed in their assessments of what was moral and what was not. Adamczewski was more reserved towards erotic content; Kądziela was more liberal. Borowy's position was hard to define due to the fact that his portions were relatively uncontroversial.

An intervention-based comparison of both editions confirms information found in the Preface by Kądziela. The majority of the $1^{\text {st }}$ edition volumes suffered the omission of one or two fragments. The difference was clearly visible in volume 6, which underwent 26 morality-related and 5 family-related interventions (regarding Żeromski's sisters). The second edition saw them reverted.

However, the situation was different in the case of volume 9 which in both editions included a considerable number of interventions. The number of omissions decreased from 58 to 15 . All fragments skipped in volume 9 were moralityrelated. They concerned Żeromski's and his mistress' venereal disease, the erotic adventures of his friend and the descriptions of sexual activities using religious metaphors, which could be seen as a kind of blasphemy. The text proper was updated with original confessions regarding his affair with Helena, autoeroticism and using the services of prostitutes.

The editing behind the scenes, including the editor's views on morality-related censorship in Dzienniki, was partially revealed through letters to Stanisław Pigoń sent by Spółdzielnia Wydawnicza "Czytelnik" publishing house and Jerzy Kądziela, written during works on the second edition of the diary. It seemed that both editors believed that the less interventions, the better. As early as 1957 Jerzy Kądziela outlined editing rules for the $2^{\text {nd }}$ edition of Dzienniki to Stanisław Pigoń. In section 2, he suggested:

When possible, the text should be kept in the original form, or at least we should not overuse censorship in its inherent functions. Those fragments which cannot be saved as well as the necessary abridgments (e.g. from Sienkiewicz's "Hania", the Russian lectures in the Warsaw Veterinary School) should be described quantitatively in a footnote ${ }^{46}$.

Therefore, the editor assumed that it would not be possible to publish the entire text. The reason was both moral and political. In a letter to Stanisław Pigoń dated 26 November 1963, Kądziela explained in detail the idea from a few years back:

\footnotetext{
${ }^{46}$ A letter by Jerzy Kądziela to Stanisław Pigoń, Warsaw 26 Nov 1957. Korespondencja Stanisława Pigonia - Kądziela Jerzy 1947-1968, manuscript BJ, ref. no. 10778 III, 1. 55.
} 
Regarding Dzienniki: just like in the $1^{\text {st }}$ edition, I would like to refrain from any interventions into the writer's texts. One section of my contract provides that I am to contribute the text as a whole: coherent, amending all previous omissions (too many and performed by editors with no thought on rules). The text A, i.e. amended with insertions, could be compared with the current version. Not soon, though, since vol. 1 has been barely moved to printing (...). If I remember correctly, vol. 1 did not contain any "problems".

There will be some, quite serious ones, in vol. 2, dealing with the beginning of an affair with Helena. I think it would be appropriate if Professor, reading vol. 2 with notes in updated typescript, expressed his view on the matter and shared his possible suggestions. Leaving everything for Mrs. Jedlicka [a Wydawnictwo "Czytelnik" editor - K.K.] to decide upon seems to be a bad idea.

Theoretically speaking, it seems prudent to retain psychological reflections on love (abundant in mature novels) and remove "factographic" drastic fragments. And, of course, we should try to retain as much political views as possible, though, judging by the experiences with the "dictionary" [Słownik współczesnych pisarzy polskich (Dictionary of contemporary Polish writers) - K.K.], will not be easy ${ }^{47}$.

The problem of whether, or to what extent, to censor, the morality-related fragments of Dzienniki was discussed many times by Kądziela, Pigoń, and "Czytelnik" representatives - mainly Wanda Jedlicka, the director of the humanities editing team, and Alicja Podzielna, her deputy (during her illness and after Jedlicka's death in 1967). In 1961, it was proposed to establish a special committee to decide upon text omissions in Dzienniki. The committee was to consist of members of the Polish Writers' Union. Those plans were cancelled after consulting Stanisław Pigon' ${ }^{48}$. Eventually, it was agreed that the omissions were to be decided upon by three parties: Pigoń, Kądziela and the editing team of "Czytelnik". Any discrepancies were to be settled by the Krakow-based editor. If the parties had been unable to reach an agreement, an arbiter would have been appointed (though it seems that such a situation had never happened) ${ }^{49}$.

When working on the first collection of Dzienniki, Pigon was in favour of retaining the highest possible coherence of the text. Wanda Jedlicka, in a letter dated 27 September 1962 assured him:

\footnotetext{
${ }^{47}$ A letter by Jerzy Kądziela to Stanisław Pigoń, Warsaw 26 November 1963. Stanisław Pigoń - Jerzy Kądziela letters between 1947-1968, manuscript BJ, ref. no. 10778 III, 1. 63.

${ }^{48}$ A letter by Jerzy Kądziela to Stanisław Pigoń, Warsaw 6 June 1961. Stanisław Pigoń-Jerzy Kądziela letters between 1947-1968, manuscript BJ, ref. no. 10778 III, 1. 59.

${ }^{49}$ A letter by Wanda Jedlicka to Stanisław Pigoń, Warsaw 19 March 1963. Stanisław Pigoń - „Czytelnik” letter, Publishing House, Humanities Department, Warsaw 1954-1968, manuscript BJ, ref. no. 10758 III, 1. 135.
} 
As far as omissions in the text are concerned, I would like to assure you that the omissions in collection 1 have been reintroduced. It is our ultimate goal to limit ourselves to a necessary minimum. This approach results from respect towards the writer's family and care for his memory ${ }^{50}$.

She used similar arguments in later correspondence as well:

I do not know if the respect for the great writer requires us to highlight or to hide the most intimate issues. What would the author want if he was to share his "confessions" with the reader? And lastly, isn't the editor discretion-bound and shouldn't he be tactful towards the author's next of kin? ${ }^{51}$

Jedlicka used the same argument as Kądziela in her attempts to resolve Pigon's doubts concerning the omissions. She was aware of the fact that the text would be censored by GUKPPiW (Main Office of Control of Press, Publications and Shows) for political reasons ${ }^{52}$. It also seemed that it was Wanda Jedlicka who advocated greater omissions in the text of the diary than Pigon or Kądziela. Some explanation of her views can be found in Pigoń's words, which she referred to in a letter dated 7 December 1963:

I believe there is no need to remove everything. If some small allusions or remarks are left, and they are not too embarrassing, then maybe they should not be necessarily removed $^{53}$.

The views of the Krakow-based editor on morality-related censorship in Dzienniki did not evolve much over all those years when she worked on Żeromski's diary. It could be seen in a letter dated 19 December 1967. Alicja Podzielna, the editor, defended herself against the accusation of "spoiling the author's image and ignoring some aspects of his character and life in general". Those accusations came from Pigon, who verified the content of the notes, which were to be pub-

\footnotetext{
${ }^{50}$ A letter from Wanda Jedlicka to Stanisław Pigoń, Warsaw 27 Sep 1962. Stanisław Pigoń - „Czytelnik” letters, Publishing House, Humanities Department, Warsaw 1954-1968, manuscript BJ, ref. no. 10758 III, 1. 131

${ }^{51}$ A letter from Wanda Jedlicka to Stanisław Pigoń, Warsaw 14 Jan 1963. Stanisław Pigoń - „Czytelnik” letters, Publishing House, Humanities Department, Warsaw 1954-1968, manuscript BJ, ref. no. 10758 III, 1. 132.

${ }^{52}$ A letter from Wanda Jedlicka to Stanisław Pigoń, Warsaw 19 Jun 1963. Stanisław Pigoń - „Czytelnik” letters, Publishing House, Humanities Department, Warsaw 1954-1968, manuscript BJ, ref. no. 10758 III, 1. 138.

${ }^{53}$ A letter from Wanda Jedlicka to Stanisław Pigoń, Warsaw 7 Dec 1963. Stanisław Pigoń - „Czytelnik" letters, Publishing House, Humanities Department, Warsaw 1954-1968, manuscript BJ, ref. no. 10758 III, 1. 144.
} 
lished as the last, separate volume of the edition. In his opinion, those should be amended with, among other things, information on Żeromski's venereal disease, and they should highlight the role of the stepmother in his affair with her sister, Helena Radziszewska, his relations with his sisters, contacts with prostitutes, and discussion on the coded notes concerning autoeroticism in the first volumes. Podzielna saw Pigon's lack of consistency in those propositions. She explained that "this and not the other meaning of Dzienniki was critical to the form of the commentary, and it was difficult to expect the commentator to highlight those fragments we are struggling to hide in the text. " ${ }^{54}$ In her defence, she referred to Pigon's own guidelines, clearly defined in his letters sent to "Czytelnik":

I am still perturbed by the issue of the text's coherence. I cannot accept the thought that the editing process was to accept, in detail, all sexual references. I am still in support of general omissions. (letter dated 14 March 1963)

Scatologies are, of course, to be reduced here and there, which I have marked separately. (letter dated 6 June 1964)

I remove only the ultimate obscenities: mostly everything relating to the disease, the Debe handbook, and the more appalling blasphemous allusions. (letter dated 3 April $1963)^{55}$.

The issue of morality-related censorship in both editions, as preserved in the documents of the GUKPPiW, stored in the Archiwum Akt Nowych [Archives of New Records], was marginal. Much more attention was paid to the political tone of Dzienniki. The GUKPPiW received a typescript censored by the "Czytelnik" and the editors. The fact was voiced in the review of the $2^{\text {nd }}$ edition of Dzienniki, dated 17 April 1953. A censor, while addressing the interventions proposed in the text, stated: "I would like to note that the editing team removed several sections concerning the erotic experiences of Żeromski" ${ }^{56}$.

The information on morality-related content was published in the review of the $2^{\text {nd }}$ edition, developed on 3 October 1962 by Władysław Kałucki. The author wrote:

The propositions of changes to the new edition of Dzienniki, filed presently by the "Czytelnik" Publishing House, concern exclusively the first part of Dzienniki and aim to reintroduce some texts which had been removed, i.e. dotted /.../, in the 1953 edition. I do not know the reasons behind those omissions. The Publishing House, in

${ }^{54}$ A letter from Alicja Podzielny (“Czytelnik” Publishing House) to Stanisław Pigoń, Warsaw 19 Dec 1967. Stanisław Pigoń - „Czytelnik” letters, Publishing House, Humanities Department, Warsaw 1954-1968, manuscript BJ, ref. no. 10758 III, 1. 164.

${ }^{55}$ Ibidem.

${ }^{56}$ AAN, GUKPPiW, ref. no. 375 (31/31), 1. 830-831. 
its preface to the first part in 1953 explained that the omissions and dotting concerned "the most intimate issues of the author". The text to be placed in the dotted sections does suggest that the original omissions resulted from, at least partially, censorship reasons. In fact, I believe that the same reasons do not allow the text to be approved for publication as a whole even today ${ }^{57}$.

Later, Kałucki listed additions proposed by the editors which, in his opinion, raised no censorship-related objections. However, he was neither meticulous (he listed only some of the additions which were introduced to the first three volumes of the new edition) nor precise (he confused dates of the omissions in the previous edition).

The review of the second collection by Irena Nowołowska, dated 25 February 1964, revealed interesting behind the scenes activities in the editing process in the case of Dzienniki. The censor wrote:

(...) The contents of the collection, when compared to the previous edition, were expanded to include the newfound material (one volume in the Soviet Union), and texts left out from the previous edition. Those were removed with the author in mind, and partially the people he wrote about and they applied to intimate matters. The current edition sees everything back. The publisher skipped only two fragments. I am sure that the reintroduction of those texts, almost exhibitionist in tone, was agreed upon with the family and the editors. Therefore, I see no need for the bureau to interfere. However, I believe that in some cases the publisher unnecessarily provides full text [two illegible words] that does not concern Żeromski directly (p. 93/4).

The information regarding the editors consulting Żeromski's family regarding Dzienniki could be found in Stanisław Pigońs letters to Monika Żeromska. She wrote:

Dear professor,

I have received your letter in Konstancin, where I came for Christmas. I will provide you with all the required material, if possible. Since I would not entrust anyone with the manuscripts, I will bring them to Krakow myself. I will stay there for a couple of days so that we can discuss the issue of Dzienniki in detail $(\ldots)^{58}$.

The letter was dated 24 December 1956, which meant that it was written after collection 3 of the $1^{\text {st }}$ edition of Dzienniki was printed. The letters be-

${ }^{57}$ AAN, GUKPPiW, ref. no. 772 (132/11), 1. 336.

${ }^{58}$ Monika Żeromska to Stanisław Pigoń, Konstancin, 24 December 1956, in: S. Pigoń, M. Żeromska, Korespondencja wzajemna (1952-1968) [Letters 1952-1968], typesetting, preface and commentary by Z.J. Adamczyk and A. Kowalczykowa, Rzeszów 2004, p. 24. 
tween Pigoń and Żeromska did not reveal any details of the promised discussion about Dzienniki, or any other in fact. Therefore, we do not know how Anna and Monika Żeromski reacted to the information about the planned $2^{\text {nd }}$ edition of the diary.

The results of the work of the editors and publishing house, also in respect of morality-related omissions, were also evaluated by the readers. One such evaluation could be found in Hanna Mortkowicz-Olczakowa's O Stefanie Żeromskim. Ze wspomnień i dokumentów [On Stefan Żeromski. Memories and Documents], published by PIW in 1965. It contained a long paragraph criticizing a number of omissions in the $1^{\text {st }}$ edition of Dzienniki:

The abridgments, arising from discretion, did no good to this bold publication. A bizarre, often shocking, collection of confessions and self-analyses was made flat. It lost the balance between reflection (sometimes naïve, and sometimes melancholic) and the male vigor bursting with energy. Those two elements - a reflection of a young, still primitive intellect and erotic, creative and passionate force - led the young life and struggled ceaselessly throughout the pages of the diary with the orphanhood, misery, sickness, Russian school, police repressions, and the narrowness of a Polish provincial town ${ }^{59}$.

The discussion on the prudery of the editors was extensive. Stanisław Pigon (Wspótczesność) and Jerzy Kądziela (Życie Warszawy) also participated in it. Its echoes could be found in letters to the editors. In his letter, Kądziela wrote:

It was only during the Christmas that I read Professor's most accurate reply to J. Łojka's article in Wspótczesność. That buffoon pretends to be from a different planet by saying that in this beautiful country there are only prudish editors frivolling, while censors stopped frivolling or may as well be extinct. Since he touched upon Dzienniki, I decided to clarify the issue to J. Stefczyk, who came to me to IBL (the Institute of Literary Research) regarding the issue. The article, partially "inspired" by me (especially in the fragments relating to Żeromski), appeared in Życie Warszawy (...). It was the first time when the issue of political omissions, and even the re-issue of Snobbizm i Postęp, was raised. (...) the article was difficult to publish (...). Several sentences and adjectives were removed ${ }^{60}$.

The fragment quoted from Kądziela's letter proved that the morality-related censorship could have been used as a disguise for institutionally conducted political

\footnotetext{
${ }^{59}$ H. Mortkowicz-Olczakowa, O Stefanie Żeromskim..., p. 69.

${ }^{60}$ A letter by Jerzy Kądziela to Stanisław Pigoń, Warsaw 2 Nov 1965. Stanisław Pigoń - Kądziela Jerzy letters between 1947-1968, manuscript BJ, ref. no. 10778 III, 1. 77.
} 
censorship and could have shifted the discussion towards areas favourable for the repressive (including in the case of freedom of speech) system. The discussion on moral taboo was, therefore, of secondary importance and the will to conduct it could have legitimised all the actions performed by the system. Kamila Budrowska stressed that by writing that:

if we discuss years 1948-1958, the moment of political doubt in 1956 increased freedom of speech on eroticism. What is more, it seems that the ability to discuss the subject became a kind of "safety valve", which allowed to diffuse social tensions ${ }^{61}$.

The analysis of the editing history of Żeromski's Dzienniki shows how many censors worked on the text, which researchers have always believed to be the basis for studying the life and the output of Żeromski. Typesetters and editors responsible for omissions worked with various goals in mind - preservation of the good name of the author, respecting the feelings of his next of kin and friends, discretion, and simply good taste. The evaluations of what was morally just and obscene varied. What is more, such elusive notions as personal beliefs, values and individual taste of editors had a significant influence on the final shape of Dzienniki. It was also symptomatic that the perception of certain content as taboo varied amongst editors and censors alike. The 1960 edition, considerably expanded in comparison to the $1^{\text {st }}$ edition to include more moral issues, showed that freedom of speech in terms of eroticism also broadened.

Apart from family, typesetters, editors and GUKPPiW officers, Żeromski's Dzienniki still has the marks of unreferenced censors who have not yet been unearthed. Yet cut out and torn out manuscript pages attest to their existence. The description of the manuscripts of the entire collection of Dzienniki mentions the issue several times. Dziennik z wiosny $1891 \mathrm{r}$. [Journal of the Spring of 1891] published in 2000 by Zdzisław Jerzy Adamczyk and Zbigniew Goliński, saw the removal of several sheets. "Who were the censors of the diary," publishers asked rhetorically, "we do not know" 62 . Did the torn out pages contain some obscene content? We can only speculate.

\section{Bibliography}

15/08/1886 entry, vol. 9. Manuscript held in the National Library of Poland, Warsaw ref. no. mf. 1330. 09/07/1886 entry, vol. 9. Manuscript held in the National Library of Poland, Warsaw ref. no. mf. 1330. 07/05/1886 entry, vol. 9. Manuscript held in the National Library of Poland, Warsaw ref. no. mf. 1330. AAN, GUKPPiW, ref. no. 375 (31/31), 1. 830-831.

AAN, GUKPPiW, ref. no. 772 (132/11), 1. 336.

${ }^{61}$ K. Budrowska, op. cit., p. 7.

${ }^{62}$ Z.J. Adamczyk, Z. Goliński, op. cit., p. 7-8. 
A letter by Jerzy Kądziela to Stanisław Pigoń, Warsaw 26 Nov 1957. Korespondencja Stanisława Pigonia - Jerzy Kądziela 1947-1968, manuscript BJ, ref. no. 10778 III, 1. 55.

A letter by Jerzy Kądziela to Stanisław Pigoń, Warsaw 6 June 1961. Stanisław Pigoń - Jerzy Kądziela letters between 1947-1968, manuscript BJ, ref. no. 10778 III, 1. 59.

A letter by Jerzy Kądziela to Stanisław Pigoń, Warsaw 26 November 1963. Stanisław Pigoń Jerzy Kądziela letters between 1947-1968, manuscript BJ, ref. no. 10778 III, 1. 63.

A letter by Jerzy Kądziela to Stanisław Pigoń, Warsaw 2 Nov 1965. Stanisław Pigoń - Jerzy Kądziela letters between 1947-1968, manuscript BJ, ref. no. 10778 III, 1. 77.

A letter from Wanda Jedlicka to Stanisław Pigoń, Warsaw 27 Sep 1962. Stanisław Pigoń- „Czytelnik” letters, Publishing House, Humanities Department, Warsaw 1954-1968, manuscript BJ, ref. no. 10758 III, 1. 131

A letter from Wanda Jedlicka to Stanisław Pigoń, Warsaw 14 Jan 1963. Stanisław Pigoń - „Czytelnik” letters, Publishing House, Humanities Department, Warsaw 1954-1968, manuscript BJ, ref. no. 10758 III, 1. 132.

A letter by Wanda Jedlicka to Stanisław Pigoń, Warsaw 19 March 1963. Stanisław Pigoń-, Czytelnik” letter, Publishing House, Humanities Department, Warsaw 1954-1968, manuscript BJ, ref. no. 10758 III, 1. 135.

A letter from Wanda Jedlicka to Stanisław Pigoń, Warsaw 19 Jun 1963. Stanisław Pigoń - „Czytelnik” letters, Publishing House, Humanities Department, Warsaw 1954-1968, manuscript BJ, ref. no. 10758 III, 1. 138.

A letter from Wanda Jedlicka to Stanisław Pigoń, Warsaw 7 Dec 1963. Stanisław Pigoń - „Czytelnik” letters, Publishing House, Humanities Department, Warsaw 1954-1968, manuscript BJ, ref. no. 10758 III, 1. 144.

A letter from Alicja Podzielny ("Czytelnik" Publishing House) to Stanisław Pigoń, Warsaw 19 Dec 1967. Stanisław Pigoń - "Czytelnik” letters, Publishing House, Humanities Department, Warsaw 1954-1968, manuscript BJ, ref. no. 10758 III, 1. 164.

Adamczyk Zdzisław Jerzy, Goliński Zbigniew, Nota wstępna, in: S. Żeromski, Dziennik z wiosny 1891 r., Kieleckie Studia Filologiczne, Kielce 2000.

Budrowska Kamila, Cenzura, tabu i wstyd. Cenzura obyczajowa w PRL-u (1948-1958), "Napis" 2012, issue 18.

Dziechcińska Hanna, Pamiętniki czasów saskich. Od sentymentalizmu do sensualizmu, Wydawnictwo Uczelniane WSP w Bydgoszczy, Bydgoszcz 1999.

Grotowska Aleksandra, "O czym się nawet myśleć nie chce” a jednak trzeba mówić. O dziełach Gabrieli Zapolskiej i ich recepcji w środowisku wspótczesnym autorce, "Napis" 2009, issue 15.

Hutnikiewicz Artur, Żeromski, PWN, Warsaw 2000.

Kalendarz życia i twórczości, S. Eile and S. Kasztelowicz (eds.), Wydawnictwo Literackie, Cracow 1976.

Kościewicz Katarzyna, Intymistyka i cenzura - na przykładzie pierwszego wydania "Dzienników" Stefana Żeromskiego, in: "Lancetem a nie maczuga". Cenzura wobec literatury i twórców w latach 1945-1965, K. Budrowskiej and M. Woźniak-Łabieniec (eds.), Wydawnictwo IBL PAN, Warsaw 2012.

Krzysztofik Małgorzata, “O niepłodności w stanach mał̇eńskich”- czyli jak XVII-wieczny kalendarzysta-lekarz omawia oraz cenzuruje tematy wstydliwe, "Napis" 2009, issue 15.

Maciejewska Iwona, "Te rzeczy...” - przejawy autocenzury w prezentowaniu treści erotycznych (na przykładzie prozy czasów saskich), "Napis” 2009, issue 15. 
Monika Żeromska to Stanisław Pigoń, Konstancin, 24 December 1956, in: S. Pigoń, M. Żeromska, Korespondencja wzajemna (1952-1968) [Letters 1952-1968], typesetting, preface and commentary by Z.J. Adamczyk and A. Kowalczykowa, Wydawnictwo Uniwersytetu Rzeszowskiego, Rzeszów 2004.

Moszczeńska Iza, Czego nie wiemy o naszych synach - fakta i cyfry dla użytku rodziców, Księgarnia Naukowa, Warsaw 1904.

Paczoska Ewa, Ideał czystości i piekto mężczyzn w literaturze drugiej połowy XIX wieku, in: Kobieta i rewolucja obyczajowa. Społeczno-kulturowe aspekty seksualności. Wiek XIX i XX,

A. Żarnowskiej and A. Szwarca (eds.), DiG, Warsaw 2006, p. 62.

Paszek Jerzy, Danae Żeromskiego, “Teksty” 1974, no. 1.

Piołun-Noyszewski Stanisław, Stefan Żeromski. Dom, dzieciństwo i młodość, Wydawnictwo J. Mortkowicz, Cracow 1928.

Rodak Paweł, Miłość w dzienniku Stefana Żeromskiego: między sztambuchem, listem i powieścia, "Pamiętnik Literacki" 2010, no 2.

Rodak Paweł, Między zapisem i literatura. Dziennik polskiego pisarza w wieku XX, Wydawnictwo Uniwersytetu Warszawskeigo, Warsaw 2011.

Utkowska Beata Sporny wzorzec rusofobii. Stefan Żeromski wobec Rosji i Rosjan w "Dziennikach" (typescript).

Zimand Roman, Diarysta Stefan Ż., Ossolineum, Wroclaw 1990.

Żeromski Stefan, Dzienniki, W. Borowy, S. Adamczewski, J. Kądziela (eds.), vol. 1-3, $1^{\text {st }}$ edition, Czytelnik, Warsaw 1953-1956.

Żeromski Stefan, Dzienniki, J. Kądziela (ed.), vol. 1-7, $2^{\text {nd }}$ edition, Czytelnik, Warsaw 1963-1970. Żeromski Stefan, Dzienników tom odnaleziony, J. Kądziela (ed.), Czytelnik, Warsaw 1973.

\section{Katarzyna Kościewicz}

\section{Routine But Ribald. Intimacy in Stefan Żeromski's Journals}

\section{(Summary)}

Stefan Żeromski's Journals concern mostly matters of intellectual (book, theatre, and exhibition reviews, writing techniques) and personal character, with the latter including some very intimate material. Żeromski was an exhibitionist in his writing. He described his autoerotic practices, his visits to brothels, details of sexual relationships with his mistresses, as well as some personal problems of his friends and acquaintances. The present analysis of the writer's Journals focuses on how Żeromski tended to write about his intimate life, what matters and to what extent were treated as taboo by the author himself, by people from his closest circle, by readers of the manuscript version of his Journals, and finally, by editors and publishers of two $20^{\text {th }}$-century editions of his work. Taking this perspective, the close reading of Żeromski's Journals will thus concentrate on issues such as private life, taboo, censorship and self-censorship.

Keywords: Stefan Żeromski, Dzienniki, censorship, self-censorship 